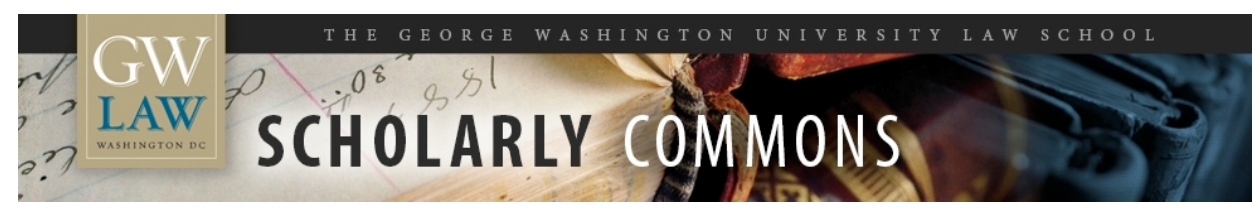

\title{
A Comparison of the Cultures and Performance of a Modern Agency and a Nineteenth-Century Agency
}

Richard J. Pierce Jr

Follow this and additional works at: https://scholarship.law.gwu.edu/faculty_publications

Part of the Law Commons

\section{Recommended Citation}

Pierce, Richard J., A Comparison of the Cultures and Performance of a Modern Agency and a NineteenthCentury Agency (2017). Richard J. Pierce, Jr., A Comparison of the Cultures and Performance of a Modern Agency and a Nineteenth-Century Agency, in ADMINISTRATIVE LAW FROM THE INSIDE OUT: ESSAYS ON THEMES IN THE WORK OF JERRY L. MASHAW 322 (Nicholas R. Parrillo ed., 2017).; GWU Law School Public Law Research Paper No. 2017-87; GWU Legal Studies Research Paper No. 2017-87. Available at SSRN: https://ssrn.com/abstract=

This Book Part is brought to you for free and open access by the Faculty Scholarship at Scholarly Commons. It has been accepted for inclusion in GW Law Faculty Publications \& Other Works by an authorized administrator of Scholarly Commons. For more information, please contact spagel@law.gwu.edu. 
This material has been published in Administrative Law From the Inside Out: Essays on Themes in the Work of Jerry L. Mashaw, edited by Nicholas R. Parrillo. This version is free to view and download for personal use only. Not for re-distribution, re-sale or use in derivative works. (C) Cambridge University Press. Book webpage: http:// www.cambridge.org/catalogue/catalogue.asp?isbn=9781107159518

\section{A Comparison of the Cultures and Performance of a Modern Agency and a Nineteenth-Century Agency}

Richard J. Pierce, Jr.*

\section{INTRODUCTION}

In his invitation to participate in this symposium to honor Jerry L. Mashaw, Professor Parrillo suggested themes that would be appropriate to address as tributes to the extraordinary contributions that Professor Mashaw has made to administrative law. I have chosen a topic that fits under Professor Parrillo's heading of "the relationship of legal culture (including judicial review) to the behavior and performance of administrative agencies." I will compare the cultures and performance of the National Highway Traffic Safety Administration (NHTSA) with the cultures and performance of the Board of Supervising Inspectors of 1852 (Board).

In a sense, everything I have ever done in the field of administrative law is attributable to Professor Mashaw. In 1969, he was my professor in a six-credit hour course called "Legislative and Administrative Law." For four decades, I taught administrative law using his casebook. ${ }^{1}$ I have learned most of what I know about the American public law system by reading the many books and articles he has written. This essay was inspired by, and borrows heavily from, the books and articles Professor Mashaw has written about the culture and performance of NHTSA and the Board. ${ }^{2}$

* I am indebted to Francesca Bignami, Marija Dordeska, Rob Glicksman, Emily Hammond, Kristin Hickman, Alexandra Klasse, Jerry L. Mashaw, Tom McGarity, Alan Morrison, Nicholas Parrillo, Joshua Schwartz, Sidney Shapiro, Paul Verkuil, Wendy Wagner, the participants in a works in progress luncheon at George Washington University School of Law and the participants in a symposium at Yale Law providing helpful comments on an earlier version of this chapter.

1 Jerry L. Mashaw, Richard A. Merrill, Peter M. Shane, Elizabeth Magill, MarianoFlorentino Cuéllar \& Nicholas R. Parrillo, Administrative law: The American Public Law System (7th ed. 2014).

2 Jerry L. Mashaw, Administration and "The Democracy": Administrative Law from Jackson to Lincoln, 1829-1861, 117 Yale. L. J. 1568, 1628-93 (2008); Jerry L. Mashaw \& David L. Harfst, The Struggle for Auto Safety (1990) [hereinafter cited as Mashaw \& Harfst, 
In section I, I describe generally the cultures and performance of NHTSA and the Board. In section II, I compare the performances of the two agencies with reference to the problem of ossification of rules and, more broadly, of serious problems in all aspects of an agency's performance of its missions. In section III, I relate those problems to the large reductions in agency resources that seem increasingly inevitable as a function of our budgeting process. In section IV, I describe some of the ways in which the excessive proceduralization of the agency decision-making process has contributed to systemic bias in the decision-making process. In section $\mathrm{V}$, I compare the rulemaking process in the US with the rulemaking process in the European Union to show that the agency culture that produced good results in the US in the nineteenth century can improve the performance of agencies in the twenty-first century. In section VI, I describe potential legal paths back to the nineteenth century legal culture in the US.

\section{THE CULTURES AND PERFORMANCE OF NHTSA AND THE BOARD}

Congress created NHTSA in $1966^{3}$ and the Board in $1852^{4}$ to perform analogous missions using identical regulatory tools. The largest single source of avoidable accidents in 1966 was the "second collision," the collision between some part of the human body and some part of the inside of a car when a car is in an accident. Second collisions caused 12,000 avoidable deaths and 100,000 avoidable injuries every year. ${ }^{5}$ The largest single source of avoidable accidents in 1852 was steamboat explosions. Thus, for instance, there were 233 steamboat explosions in 1848; a single explosion in St. Louis in 1849 destroyed 23 steamboats; and a single steamboat explosion in 1864 killed 1647 people. ${ }^{6}$

Congress provided each agency with one primary tool to perform its mission - rulemaking. The performance of the agencies varied dramatically, however. Within two years of its creation, the Board had issued scores of rules that had the effect of reducing loss of life attributable to steamboat explosions by 75 percent and property damage caused by steamboat explosions by

Auto Safety]; Jerry L. Mashaw \& David L. Harfst, Regulation and Legal Culture: The Case of Motor Vehicle Safety, 4 Yale J. Reg. 257 (1987) [hereinafter Mashaw \& Harfst, Regulation and Legal Culture].

3 National Traffic and Motor Vehicle Safety Act of 1966, Pub. L. No. 89-563, 8o Stat. 718 (1966) (codified at 15 USC $\iint 1381-1431$ ).

4 Act of Aug. 30, 1852, ch. 106, 10 Stat. 61.

5 The Supreme Court accepted the agency's estimates for purposes of judicial review. Motor Vehicle Manufacturers Ass'n v. State Farm Mutual Automobile Ins. Co, 463 US 29, 35 (1983).

${ }^{6}$ American Experience, People and Events: Steamboat Disasters (PBS Home 2015). 
90 percent. 7 The rules were wide-ranging. They addressed issues like licensing of steamboat officers, certification and inspection of boilers, specifications for the permissible diameter and operating pressure of boilers, navigation rules for steamboats, and mandatory signs in staterooms that informed passengers of the location of life preservers. ${ }^{8}$ By contrast, it took NHTSA twenty-three years to issue the rule that had by far the greatest beneficial effect on highway safety - the passive restraint (airbag) rule. 9 The agency's frustration as a result of that lengthy and resource-intensive effort induced it to abandon the tool of rulemaking almost entirely and to devote most of its scarce resources to an alternative - recalls of defective automobiles-that has had little beneficial effect. ${ }^{10}$ In Professor Mashaw's words, NHTSA's abandonment of rulemaking was "the virtual abandonment of its safety mission."

It is impossible to identify and to account for the many changes in the political environment that may explain part of the difference between the performance of the Board and NHTSA, but it seems likely that the dominant source of the differing performances of the Board and NHTSA was differences in legal culture. The Board was subject to only one mandatory procedure. It was required to provide written reasons for each decision it made. ${ }^{12}$ None of its actions were subject to judicial review. ${ }^{13}$ NHTSA was required to comply with the notice and comment procedure described in section 553 of the Administrative Procedure Act (APA). ${ }^{14}$ More importantly, NHTSA rules are subject to pre-enforcement judicial review.

One difference in results illustrates well the effects of pre-enforcement judicial review. The Board was required to provide "written reasons" for every rule it issued, while NHTSA was required to provide a "concise general statement of basis and purpose" for every rule it issued. The two procedural requirements sound the same, but they varied dramatically because of the effects of pre-enforcement judicial review. A typical Board statement of reasons was a few paragraphs long. It was written to explain the basis for the Board's action to its superiors in the White House, Congress, and the public at large. ${ }^{15} \mathrm{~A}$ typical NHTSA statement of basis and purpose is hundreds of pages long.

7 Mashaw, supra note 2, at 1647. $\quad 8$ Id. at 1644-46.

9 Mashaw \& Harfst, Auto Safetr, supra note 2, at 211. The passive restraint rule saved more lives than all of the other rules NHTSA issued combined. Id. at 85 .

10 Jerry L. Mashaw and David Harfst, The Transformation of Auto Safety Regulation: Bureaucratic Adaptation to Legal Culture (Dec. 14, 2015), available at http://papers.ssrn.com/ sol3/papers.cfm?abstract_id=2703370.; Mashaw \& Harfst, Auto Safety, supra note 2, at 11, 69, 199-201; Mashaw \& Harfst, Regulation and Legal Culture, supra note 2, at $263-64$.

11 Auto Safetr, supra note 2, at $11 . \quad{ }_{12}$ Mashaw, supra note 2, at 1641-42.

13 Id. at 1669-84. ${ }^{14} 5$ USC $\int 553 . \quad 15$ Mashaw, supra note 2, at 1656-57. 
Thus, for instance, the statement of basis and purpose that accompanied the passive restraint rule was 750 pages long. ${ }^{16}$ It was written to explain the basis of the rule to NHTSA's superiors in the judiciary. It is unimaginable that a NHTSA statement of the basis and purpose of a rule would ever be read by NHTSA's political superiors or by any member of the public at large. As shaped by courts, the statements of basis and purpose required by the APA have "metastasize[d] into the book-length treatises that one now often finds in the Federal Register." ${ }^{17}$

Until 1875, the Supreme Court repeatedly and consistently held that agency actions were not subject to judicial review if they required the exercise of any discretion. ${ }^{18}$ The only executive actions that were subject to judicial review were mandatory ministerial acts that required no exercise of discretion. ${ }^{19}$ As a result, federal courts could not, and did not, review any rule issued by the Board.

As Professor Merrill has described in detail, ${ }^{20}$ the Supreme Court's approach to judicial review of agency actions changed gradually between 1875 and 1946 . The Supreme Court began to authorize lower courts to review agency actions using an appellate review model. In 1946, Congress codified this approach by enacting the APA. ${ }^{21}$ That statute instructed courts to review final agency actions $^{22}$ except "so far as... agency action is by law committed to agency discretion." 23

The APA also required agencies to use a particular procedure to issue a rule that has the force of law. As written, the three-step process for issuing rules described in APA section 553 is simple, sensible, and efficient. An agency must issue a notice of proposed rulemaking, solicit comments from the public in response to the notice, and issue a final rule that incorporates a concise general statement of the basis and purpose of the rule. The APA describes the three steps in the following language:

(b) General notice of proposed rule making shall be published in the Federal Register.... The notice shall include-

16 Mashaw \& Harfst, Auto Safety, supra note 2, at 210-11.

17 Mashaw, supra note 2, at 1656.

18 E.g., Gaines v. Thompson, 74 US (7 Wall) 347, 352-53 (1868); Reeside v. Walker, 52 US (11 How.) 272 (1850); Decatur v. Paulding, 39 US (14 Pet.) 497, 515-16 (1840). See generally Nicholas Bagley, The Puzzling Presumption of Reviewability, 127 Harv. L. Rev. 1285, 1294-1302 (2014).

19 Marbury v. Madison, 5 US (1 Cranch) 137, 163, 170 (1803).

20 Thomas Merrill, Article III, Agency Adjudication, and the Emergence of the Appellate Review Model, 111 Colum. L. Rev. 939, 953-65 (2011).

${ }^{21}$ For the history of the enactment of the APA, see George Shepherd, Fierce Compromise: The Administrative Procedure Act Emerges from New Deal Politics, 9o Nw. U. L. Rev. 1557 (1996).

$22 \quad 5$ USC $\$ 704 . \quad 23 \quad 5$ USC $\$ 701(\mathrm{~b})$. 
(1) a statement of the time, place, and nature of public rule making proceedings;

(2) reference to the legal authority under which the rule is proposed; and

(3) either the terms or substance of the proposed rule or a description of the subjects and issues involved...

(c) After notice required by this section, the agency shall give interested persons an opportunity to participate in the rule making through submission of written data, views, or arguments with or without opportunity for oral presentation. After consideration of the relevant matter presented, the agency shall incorporate in the rules adopted a concise general statement of their basis and purpose.

Until 1967, agencies complied with APA section 553 as that provision was written. In a typical rulemaking, the agency issued a relatively brief notice that complied with 553 (b), received and considered comments that were modest in length, and then issued a final rule that incorporated a "concise general statement of basis and purpose" that was only a few pages long. ${ }^{24}$ The agency practice of compliance with APA section 553 as it is written ended as a result of a series of court opinions that were issued between 1967 and 1973. Those opinions changed the meaning of section 553 in ways that render it unrecognizable when compared with the language of section 553 .

The Supreme Court's 1967 opinion in Abbott Laboratories v. Gardner $^{25}$ opened the door to a series of lower court opinions that "interpreted" section 553 to mean something dramatically different from the simple efficient decision-making process described in the APA. In Abbott, the Court announced a new test for determining whether a rule is ripe for preenforcement review. The Court announced and applied for the first time a presumption of reviewability so strong that it trumped the language of statutes. ${ }^{26}$ Like most regulatory statutes, the statute at issue in Abbott explicitly provided a means through which a party could seek review of a rule - by challenging its validity in an enforcement proceeding initiated by the agency against the party. The statute did not authorize a court to engage in pre-enforcement review of a rule. The Court applied the new presumption of reviewability to reverse the normal process for determining whether Congress has authorized a court to act. Instead of asking whether Congress authorized pre-enforcement review, the Court asked whether there was "clear and convincing evidence" that Congress intended to preclude pre-enforcement review. ${ }^{27}$ The Court

24 Jack Beerman \& Gary Lawson, Reprocessing Vermont Yankee, 75 GeO. W. L. Rev. 856 (2007).

${ }_{25} 387$ US $136(1967) . \quad{ }^{26}$ Id. at 140. See generally Bagley, supra note 18, at 1304-09.

27387 US at 141. 
concluded that the presence of a statutory provision that authorized review of a rule in an enforcement proceeding and the absence of a statutory provision that authorized pre-enforcement review of a rule were not enough to satisfy the "clear and convincing evidence" standard that the Court announced to accompany its newly announced presumption in favor of pre-enforcement review of rules. Around the same time the Court authorized pre-enforcement review of rules, Congress began to enact regulatory statutes that purported to authorize pre-enforcement review of rules. The National Highway Traffic Safety Act was one of the first statutes that included such a provision. ${ }^{28}$

The Abbott opinion also stretched the Article III requirement of a "Case or Controversy" as a prerequisite to federal court jurisdiction to, or perhaps beyond, its breaking point. As Professor Mashaw has noted, prior to Abbott, the Case or Controversy Clause was understood to bar judicial review of abstract issues such as the abstract validity of a rule. ${ }^{29}$ The validity of a rule could be challenged in an enforcement proceeding in which the government relied on the rule, but only as "a by-product of the need to determine individual rights" "on the basis of particular facts." 30

Before Abbott, most rules were subject to review only in an enforcement proceeding. After Abbott, a rule was subject to pre-enforcement review if, like most rules, it presents a legal issue that is "fit for judicial resolution" and "requires an immediate change in the plaintiffs' conduct of their affairs with serious penalties attached to noncompliance ...." "31

The stark differences between the review of a rule in an enforcement proceeding and the pre-enforcement review of a rule became apparent within a few years of the Court issuing its opinion in Abbott. When a rule was reviewed in the context of an enforcement proceeding, it was usually reviewed by a district court that used the record of the enforcement proceeding as the basis for review. Since agencies usually exercise their prosecutorial discretion to bring an action to enforce a rule only when the target of the enforcement action has engaged in conduct that is particularly egregious and obviously harmful, the record in the enforcement proceeding typically included evidence that illustrated the need for the rule in a specific context in which violation of the rule caused serious damage. As a result, an agency was likely to prevail in an action in which the target of an enforcement action sought review of the rule. Rules were rarely challenged because a regulated firm knew that it was unlikely to prevail when it attempted to challenge the validity of the rule in an enforcement proceeding. The firm also knew that it was vulnerable to serious

28 Mashaw \& Harfst, Auto Safety, supra note 2, at 157.

29 Id. at $156-58 . \quad 30 \mathrm{Id}$. at $157 . \quad 31 \quad 387 \mathrm{US}$ at 153. 
direct and indirect adverse consequences if it violated the rule, challenged the validity of the rule in an enforcement proceeding, and lost.

By contrast, any firm that dislikes a rule has an incentive to seek preenforcement review of the rule knowing that it will suffer no adverse effects if it loses. Within a few years of the Court's decision in Abbott, it became apparent that a regulated firm also has a much better chance of prevailing in a proceeding in which it seeks pre-enforcement review of a rule than when it challenges the validity of the same rule in a proceeding to enforce the rule. In most cases, pre-enforcement review takes place in a circuit court rather than a district court. The circuit court has an understandable desire to have access to some kind of record that it can use as the basis for review. It does not have access to the record of an enforcement proceeding for that purpose, so it uses a "record" that consists of the notice, the comments filed in response to the notice, and the "concise general statement" of the rule's basis and purpose that the agency is required to incorporate in the final rule.

In Automotive Parts E. Accessories Ass'n v. Boyd, ${ }^{2}$ one of the first preenforcement review cases decided after the Supreme Court issued its opinion in Abbott, the D.C. Circuit stated that it needed access to a record sufficient to allow it to engage in pre-enforcement review of a rule. The court then described the conflict between the record that is created when an agency complies with APA section 553 and the kind of record the court thought that it needed to engage in pre-enforcement review of a rule. The court resolved that conflict by instructing agencies to take the actions needed to develop the kind of record the court considered necessary to allow it to engage in review rather than to comply with the requirements Congress described in APA section 553. In the court's words:

[It] is appropriate for us to remind the Administrator of the ever present possibility of judicial review, and to caution against an overly literal reading of the statutory terms 'concise' and 'general.' These adjectives must be accommodated to the realities of judicial scrutiny, which do not contemplate that the court itself will, by a laborious examination of the record, formulate in the first instance the significant issues faced by the agency and articulate the rationale of their resolution. We do not expect the agency to discuss every item of fact or opinion included in the submissions made to it in informal rule making. We do expect that, if the judicial review which Congress has thought it important to provide is to be meaningful, the "concise general statement of $* * *$ basis and purpose' mandated by Section 4 will enable us to see what major issues of policy were ventilated by the informal proceedings and why the agency reacted to them as it did. 33

$$
32 \quad 407 \text { F.2d } 330 \text { (D.C. Cir. 1968). } 33 \text { Id. at } 338 .
$$


The court went on to hold that the three-page "concise general statement of basis and purpose" that the agency had incorporated in the rule was sufficient to allow the court to uphold the rule because the petitioner did not file detailed and well-supported comments that criticized the rule proposed in the notice. 34

The members of the D.C. Bar immediately internalized and acted on the message the D.C. Circuit sent in Auto Parts. Lawyers for regulated firms that disliked a rule proposed by an agency began to submit lengthy and detailed comments that criticized the rule, often accompanied by consultants' reports that included findings and conclusions that undermined the basis for the rule. Thus, for instance, when the National Highway Safety Administration proposed another rule shortly after its "victory" in Auto Parts, a trade association that disliked the proposed rule submitted lengthy comments that criticized in detail every aspect of the agency proposal. 35 The comments were accompanied by the reports of studies conducted by consulting firms retained by the association that found that the proposed rule was unnecessary and that its implementation would be costly and dangerous. The association prevailed in the pre-enforcement review proceeding it initiated based on the D.C. Circuit's conclusion that the final rule was arbitrary and capricious because the agency had not responded adequately to the comments filed by the association that were critical of the proposed rule..$^{6}$

That pair of D.C. Circuit opinions created an entirely new legal environment. Every circuit has followed the lead of the D.C. Circuit in holding that an agency rule is arbitrary and capricious unless the agency responds adequately to all well-supported comments that are critical of the rule proposed by the agency, and the Supreme Court's 1983 opinion in Motor Vehicle Manufacturers' Ass'n v. State Farm Mutual Automobile Insurance Co. ${ }^{37}$ has been widely interpreted to approve of the D.C. Circuit approach. The Supreme Court also added a seemingly open-ended duty to consider alternatives to any action an agency proposes to take in a rulemaking.

Not surprisingly, those judicial opinions have created incentives for parties that dislike proposed rules to bury an agency with comments that criticize the proposed rule and suggest alternatives to the proposed rule..$^{3}$ Comments on

34 Id. at $33^{8-41 .}$

35 National Tire Dealers and Retreaders Ass'n v. Brinegar, 491 F.2d 31, 36-40 (D.C. Cir. 1974).

${ }^{36} \mathrm{Id}$. at $40-41$.

37463 US 29 (1983). See generally 1 Richard Pierce, Administrative Law Treatise $\$ 7 \cdot 4$ (5th ed. 2010).

$3^{8}$ Professor Wagner discusses this phenomenon at length in Wendy Wagner, Administrative Law, Filter Failure, and Information Capture, 59 DUKE L. J. 1321, 1353-65 (2010). 
economically significant proposed rules often total tens of thousands of pages, including consultant studies that purport to undermine the bases for the proposed rule. Agencies regularly require years to draft the several-hundred-page "concise general statement of basis and purpose" that must be incorporated in an economically significant rule, and courts reject 30 percent of the rules as arbitrary and capricious because the agency did not adequately respond to one or more of the voluminous critical comments. 39 In short, the courts converted the statutory requirement for a "concise general statement of basis and purpose" into a judicial requirement for a detailed and encyclopedic document that invariably spans hundreds of pages in the context of economically significant rules.

Shortly after the Supreme Court issued its opinion in Abbott, circuit courts began a similar process of rewriting the APA notice requirement. APA section 553 requires an agency to issue a "general notice" that consists of:

(1) a statement of the time, place, and nature of public rule making proceedings;

(2) reference to the legal authority under which the rule is proposed; and

(3) either the terms or substance of the proposed rule or a description of the subjects and issues involved ... ${ }^{40}$

As was true of the requirement for a "concise general statement of basis and purpose," before the Court decided Abbott, agencies complied with the modest notice requirement in APA section 553 by publishing notices that were just a few pages long but that complied fully with the language of the APA. That changed as courts redefined the requirements of the APA.

The post-Abbott judicial opinion that began the process of redefinition of the notice requirement Congress created in the APA was issued by the Third Circuit in $1972 .^{41}$ The court held a notice inadequate because it did not inform the public of all of the possible ways in which the agency might change the rules it proposed to amend. All circuits soon adopted that demanding method of determining the adequacy of a notice. All circuits now hold that a notice is inadequate if the final rule is not a "logical outgrowth" of the notice..$^{22}$ The practical effect of the "logical outgrowth" test is to require agencies to attempt to identify and describe in a notice every conceivable version of the final rule the agency might adopt years later. 43

The D.C. Circuit joined in the process of redefining the notice requirement a year later. In 1973, the D.C. Circuit rejected an agency rule because the rule

39 Richard Pierce, What Do the Studies of Judicial Review of Agency Actions Mean?, 63 Admin. L. REV. 77 (2011).

$4^{\circ} 5$ USC $\int 553$ (b). $\quad 4^{1}$ Wagner Electric Corp v. Volpe, 466 F.2d 1013 (3d Cir. 1972).

42 Pierce, supra note 37 , at $\$ 7 \cdot 3 . \quad 43$ Beerman \& Lawson, supra note 24 , at 895-99. 
was based in part on a source of data that the agency had not identified in its notice. ${ }^{44}$ All circuits quickly embraced that dramatic judicial expansion of the "general notice" requirement that Congress imposed in the APA.45 All circuits now hold that "an agency commits serious procedural error when it fails to reveal portions of the technical basis for a proposed rule in time to allow for meaningful commentary" 46 and that the notice "must provide sufficient information to permit adversarial critique." 47 The practical effect of this judicially imposed duty is to require an agency to anticipate at the time it issues a notice all of the sources of data and analysis that it may want to rely on years later when it issues a final rule. The agency also must issue a supplemental notice and provide a new opportunity to comment if it decides to rely on a source of data or analysis that did not become available until after it issued its initial notice..$^{8}$ That is a routine occurrence, since a major rulemaking typically requires years to complete.

Professors Wagner, Barnes, and Peters have described the results of the dramatic judicial expansions of the modest requirement to issue a "general notice" that Congress imposed in APA section 553. The pre-notice part of the rulemaking process now takes more than twice as long as the post-notice part of the process because "the courts have made it painfully clear that if a rule is to survive judicial review, it must be essentially in final form at the proposed rule stage." 49 When the judicial expansions of the congressional requirement of a "concise general statement of basis and purpose" are added to the judicial expansions of the congressional requirement of a "general notice" of proposed rulemaking, the judicial version of APA section 553 bears no relationship to the requirements imposed by the statute.

Professor Mashaw has documented in detail the effects of judicial review on NHTSA. He concluded that reviewing courts have been "disabling,"50 "debilitating," 51 "obstructionist," 52 and "the legal embodiment of inertia." 53 He provided a one paragraph summary of the effects of the review process:

The primary demands of the legal culture of regulation - that regulatory policy be subject to the rule of law through judicial review and procedurally open to affected interests - have been much in evidence throughout the

44 Portland Cement Ass'n v. Ruckelshaus, 486 F.2d 375 (D.C. Cir. 1973).

45 Pierce, supra note 37 , at $\$ 7.3$.

$4^{6}$ Connecticut Light \& Power Co. v. NRC, 673 F.3d 525, 530-31 (D.C. Cir. 1982).

47 Home Box Office v. FCC, 567 F.2d 9, 55 (D.C. Cir. 1977).

$4^{8}$ Chamber of Commerce v. SEC, 443 F.3d 890, 908 (D.C. Cir. 2006).

49 Wendy Wagner, Katherine Barnes \& Lisa Peters, Rulemaking in the Shade: An Empirical Study of EPA's Air Toxic Emissions Standards, 63 Admin. L. Rev. 99, 110, 144 (2011).

50 Mashaw \& Harfst, Auto Safety, supra note 2, at 315.

$5^{1}$ Id. at $305 . \quad 5^{2}$ Id. at $249 . \quad 53$ Id. at 249. 
history of federal motor vehicle safety regulation. Indeed, as we have seen, these demands have been mutually reinforcing. Judicial review has been "proceduralized"... And by focusing on "process rationality," the judiciary has leveraged both the strategic and the legal positions of regulatory participants. Not only must the agency listen with care, but participants may use their access to provide multiple grounds for later reversal of the agency's choices. 54

Professor Mashaw also used a colorful analogy to capture the role of the courts: "It seemed that NASA had made it to the moon and back because its engineering judgments were not subject to judicial review." 55

The presence or absence of judicial review had major effects on the structure and internal operation of the Board and NHTSA. The Board was staffed by engineers with experience in boiler design and operation. It used informal, unregulated methods of obtaining the information needed to issue a rule presumably some combination of the expertise of the Board members and discussions with other experts known to the Board members. When the Board needed legal assistance, it asked the Attorney General for a legal opinion ${ }^{6}$ or reported to a US Attorney someone who repeatedly violated the law and defied the Board. ${ }^{5}$

When it began operating in 1966, NHTSA also was dominated by engineers. ${ }^{5}$ A decade later, however, the agency was dominated by lawyers. ${ }^{59}$ In Professor Mashaw's words, a "detailed look inside NHTSA as events unfolded during the crucial decade of the 1970s reveals the signal importance of the law in empowering bureaucratic actors and establishing the agency's internal standards of success or failure."60 And it was the translation of law by courts through the review process that produced near paralysis within NHTSA. As Professor Mashaw explained, "[i]t will be only natural for [agency] staff to become more risk averse than the judiciary that poses the outside threat. ... Even a modest judicial demand for an adequate reasoning process can translate into bureaucratic paralysis ...."61

\section{RULEMAKING OSSIFICATION AND OTHER COSTS OF MODERN AGENCY LEGAL CULTURE}

Many studies of the modern administrative process have described the effects of legal culture under the general heading of rulemaking ossification. ${ }^{62}$

54 Id. at 225. $\quad 55$ Id. at $122 . \quad 56$ Mashaw, supra note 2, at $1644 . \quad 57$ Id. at 1650.

58 Mashaw \& Harfst, Auto Safety, supra note 2, at $172 . \quad 59$ Id. at 174.

60 Id. at $175 . \quad 61$ Id. at 298.

62 Richard Pierce, Rulemaking Ossification Is Real, 80 GEO. W.L. Rev. 1493 (2012). See also Scott Atherley, Federal Agency Compliance with Congressional Regulatory Deadlines, R StreEt 
Ossification refers to the tendency of agencies to refrain from attempting to issue needed rules, delay in the process of issuing rules, and refusal to amend or to rescind rules that have become obsolete because of the magnitude of the resources agencies must devote to the rulemaking process and the amount of time it takes to issue, amend, or rescind an economically significant rule in the modern legal culture..$_{3}$

The costs of ossification are illustrated well by the delay in NHTSA's issuance of a passive restraint rule that could satisfy the courts. The direct costs of the modern legal culture in the context of the passive restraint rule include 240,000 lost lives and 2,000,000 injuries. ${ }^{64}$ If NHTSA had been operating in the nineteenth-century legal culture, it would have been able to replicate the performance of the Board. It would have issued the passive restraint rule and many other life-saving rules within two years of its creation. ${ }^{65}$

The indirect costs of NHTSA's lengthy and expensive experience with modern legal culture may be even higher, but they are hard to estimate. NHTSA largely abandoned its use of rulemaking after its experience with the passive restraint rule. ${ }^{66}$ We will never know how many more lives NHTSA would have been able to save if it had been able to replicate the performance of the Board and to issue scores of additional safety rules during its first few years of existence.

The costs of ossification are not unique to the auto safety context. Thus, for instance, the social security disability decision-making process has long been handicapped by ossification of the rulemaking process. The "grid rule" illustrates the problem. Before 1978, the Social Security Administration (SSA) relied on a large number of "vocational experts" to testify in disability hearings with respect to the jobs available to someone with the characteristics of the applicant. ${ }^{67}$ In 1978 , SSA acted on a suggestion from a team of scholars led by Professor Mashaw ${ }^{68}$ and issued the "grid rule." 69 That rule had the effect of replacing the testimony of a vocational expert in most cases. Administrative law judges (ALJs) were instructed to enter the age, education, experience, and health state of an applicant in a grid that would then yield one of two

Policy Study No. 39 (Aug. 4, 2015) (agencies failed to comply with 1400 statutory deadlines for issuing rules between 1995 and 2014). But see Jason Yackee \& Susan Yackee, Testing the Ossification Thesis, 8o Geo. Wash. L. Rev. 1414 (2012).

63 Richard Pierce, Seven Ways to Deossify Agency Rulemaking, 47 Admin. L. Rev. 59 (1995).

${ }^{6}$ See supra text accompanying note $5 . \quad 65$ See supra text accompanying notes 7-8.

${ }^{66}$ See supra text accompanying note 10. ${ }^{6} 7$ Heckler v. Campbell, 461 US 458, 461 (1983).

68 Jerry L. Mashaw, Charles J. Goetz, Warren F. Schwartz, Paul R. Verkuil \& Milton M. Carrow, Social Security Hearings and Appeals 79-87 (1978).

6943 Fed. Reg. 55,349 (1978), codified at 20 CFR \$ 404.1566. 
results - either a description of one or more jobs that could be performed by the applicant or a finding that there were no jobs available for such an applicant.

For a decade or so, the grid rule produced results far superior to the prior reliance on the testimony of vocational experts. The grid rule saved decisionmaking time, enhanced efficiency, reduced the resources needed to make disability decisions, and improved both the accuracy and the consistency of the decision-making process. Over time, however, the grid rule lost value because it was not regularly amended to reflect the myriad changes in the dynamic US economy. In 2014 the Washington Post described the problem with an illustration of the obsolescence of the grid rule. The list of jobs SSA uses to apply the grid rule "lists a 'web worker' as someone who repairs fishing nets (a heavy duty job ... fit only for the strong and able)."70 Officially, SSA has never heard of information technology or the Internet. The problem does not lie in agency incompetence but in rulemaking ossification. SSA is not willing and able to divert from its other important tasks the enormous resources required to amend the grid rule in a timely manner when rulemaking is subject to modern legal culture.

The grid rule is far from unique in this respect. SSA has long had a "treating physician" rule that makes it difficult for an ALJ to make any finding that is inconsistent with an opinion expressed by any physician who has treated the applicant even when the opinion is poorly supported and is contradicted by the well-supported opinions provided by physicians who consult for SSA..$^{71}$ The treating physician rule has been the subject of harsh criticism for decades. The critics include the six scholars who studied SSA decision-making under the leadership of Professor Mashaw in $1978,7^{72}$ nine Supreme Court Justices in $2003,{ }^{73}$ and the Administrative Conference of the United States in $2013 .{ }^{74}$ Yet SSA has not even begun the process of deciding whether to rescind or amend the treating physician rule after decades of criticism of the rule.

The indirect costs of rulemaking ossification appear in many other forms. Every proceeding to issue, amend, or rescind a major rule requires an agency to commit significant resources to the proceeding for five to ten years. That, in turn, reduces the resources agencies have available to perform other functions. That reduction is coupled with reductions in available resources attributable to

70 David A. Fahrenthold, It's Just Maddening. There Is Nothing You Can Do, Washington Post, October 18, 2014, at 1.

${ }^{71} 20$ CFR $\int 404.1527(\mathrm{~d})(2) . \quad 7^{2}$ Mashaw et AL., supra note 68, at 54-60.

73 Black \& Decker Disability Plan v. Nord, 538 US 822 (2003).

74 Administrative Conference of the United States, Disability Benefits Program: Assessing the Efficacy of the Treating Physician Rule (2013). 
the decreases in appropriations to agencies required by increasingly stringent fiscal policy limits on discretionary spending. ${ }^{75}$

The results are apparent across the federal government. Thus, for instance, the average time to resolve an immigration case is now 600 days, and the Justice Department expects to begin hearings in nonpriority cases in four years $;^{76}$ customer service provided by the Internal Revenue Service is at its lowest level in history, with over half of taxpayers unable to reach anyone on the IRS helpline and the agency unable to answer millions of written questions from taxpayers; 77 and the Department of Veterans Affairs' (DVA) scandalous inability to provide timely service to veterans has resulted in the deaths of many veterans before DVA got around to processing their requests for medical assistance or benefits. ${ }^{7}$ Even the White House office that reviews major agency rules is so understaffed that it cannot perform its responsibilities in a timely manner. ${ }^{79}$

\section{THE COSTS OF EXCESSIVE PROCEDURALIZATION \\ OF RULEMAKING WILL INCREASE}

Each of the costs of excessive proceduralization of rulemaking illustrated in the prior section is attributable to the large and growing gap between the missions Congress assigns agencies and the resources agencies have available to perform those missions, given the procedures courts require agencies to use to perform those missions. This gap will grow significantly over the next decade and beyond. The Congressional Budget Office (CBO) projects an increase in spending on Social Security and Medicare from 12.5 percent to 14.2 percent of GDP and an increase in interest on the national debt of

75 See infra text accompanying notes 79-80.

${ }^{6}$ Devlin Barrett, Save the Date: Immigrants Face Judge in 2019, WALL ST. J., Jan. 29, 2015, at A6.

77 National Taxpayer Advocate, Annual Report to Congress ix (2014).

$7^{8}$ The VA scandal has produced many reports and lots of congressional testimony from the DVA Inspector General (IG). See Department of Veterans Affairs, Office of Inspector General, March 2015 Highlights. There is reason to believe the situation is actually worse than the IG described in his reports and testimony. See Donovan Slack, VA Doesn't Release 140 Vet Health Care Probe Findings, USA Today, March 8, 2015; Emily Wax-Thibodeaux, Lead Investigator of Wait Times at Veterans Affairs Still Gets Criticism of Report, Washington Post, Nov. 1, 2014.

79 See statement of John Graham, former Director of the Office of Information and Regulatory Affairs, quoted in Energy \& Environment Daily (Mar. 20, 2015); Alex Bolton, RacheL Potter \& Sharece Thrower, Presidential Oversight and Regulatory Delay: How Politics and Organizational Capacity Influence OIRA Rule Review (2014); Curtis Copeland, Length of Rule Reviews by the Office of Information and Regulatory Affairs, Report to the Administrative Conference of the United States (2013). 
1.2 percent to 3.0 percent between 2015 and $2024 .{ }^{80}$ Depending on whether $\mathrm{CBO}$ assumes adoption of the budget preferred by Congressional Republicans or the budget proposed by President Obama, CBO projects a decrease in discretionary domestic spending over that decade of 6.5 percent to 5.1 percent or 6.4 percent to 4.5 percent of GDP. That implies a reduction in the resources available to agencies to perform their missions of 21 percent to 29 percent over the next decade.

In short, the country cannot sustain its present combination of agency missions, agency resources, and judicially mandated agency decision-making procedures. The options to create a sustainable government include a large increase in taxes, a large reduction in agency missions, a large reduction in the cost of judicially mandated procedures or some combination of the three. That choice should be easy to make, particularly given the adverse effects of the judicially mandated procedures for rulemaking on the quality of the resulting rules. Reducing the cost of judicially mandated procedures would at least reduce the magnitude of the tax increases and reductions in agency missions that will be needed to maintain a sound fiscal policy in an environment in which increases in entitlement spending account for a constantly increasing share of tax revenue.

\section{JUDICIALLY MANDATED RULEMAKING PROCEDURES} INCREASE BIAS IN OUTCOMES

The high cost of judicially mandated rulemaking procedures might be worth paying if there was reason to believe that those procedures produce improved outcomes. There is no evidence to support that belief. Instead, studies have found that the notice-and-comment process, as it has been interpreted and applied by courts, contains many sources of systemic bias in favor of regulated firms.

The first robust finding of the studies is that the most important part of the decision-making process takes place before the agency issues its notice of proposed rulemaking. ${ }^{81}$ The pre-notice part of the decision-making process takes about twice as long as the post-notice part of the decision-making

80 Congressional Budget Office, The Economic Outlook for 2015 to 2024 (2015). See also William Galston, A Budget Hemmed in By Reality, Wall Street Journal, Feb. 4, 2015, at A13; Richard Pierce, The Battle to Protect the American Public Will Become Even More Difficult, 79 G.W. L. Rev. 845 (2011) (book review); Richard Pierce, Judicial Review of Agency Actions in a Period of Diminishing Agency Resources, 49 Admin. L. Rev. 61 (1996).

${ }^{81}$ Kimberly Krawiec, Don't "Screw Joe the Plumber": The Sausage-Making of Financial Reform, 55 Ariz. L. Rev. 53, 70-71 (2013); Wagner et al., supra note 49, at 110-13. 
process. ${ }^{82}$ The agency's goal in the pre-notice part of the decision-making process is to render the post-notice process of receiving and considering comments irrelevant by publishing a proposed rule that is virtually identical to the final rule. The pre-notice decision-making process consists primarily of a large number of private meetings with individuals and firms that have an interest in the outcome of the process. Thus, for instance, agency decision-makers had 450 meetings with interested parties before they published the notice in the proceeding to issue the Volcker Rule - the rule that arguably was the most important one issued to implement the Dodd-Frank Act. ${ }^{83}$ Similarly, EPA decision-makers had an average of 178 meetings with interested parties before EPA published the notices that led to the issuance of each of 90 air toxic emission standards. $^{84}$

The pre-notice meetings are dominated by regulated parties and the law firms and trade associations that represent them. Thus, for instance, 93.1 percent of the pre-notice meetings with decision-makers in the Volcker rulemaking were with financial institutions or their representatives while parties with interests in strict regulation of financial organizations accounted for only 6.9 percent $\%$ of those meetings. ${ }^{85}$ The disproportion was even greater in the ninety EPA rulemakings. On average, regulated firms had 170 times more meetings with agency decision makers than did representatives of potential beneficiaries of the rules. ${ }^{86}$ In over half of the EPA rulemakings, only regulated firms and their representatives met with decision makers before EPA issued its notice. ${ }^{87}$ Not surprisingly, the studies produce a robust finding that regulated firms have far greater influence over the substance of a proposed rule than do potential beneficiaries of the rule. ${ }^{88}$

The bias in favor of regulated firms continues in the post-notice period. In many rulemakings, the largest number of comments by far come from individuals who prefer strict regulation. ${ }^{89}$ Virtually all of those comments are worthless to decision-makers, however. They consist of little more than slogans that are more appropriate as bumper stickers than as contributions to a decision-making process - e.g., "protect us from being poisoned by polluters" or "protect us from thieving bankers." 90

82 Wagner et al., supra note 49 , at 144-45. $\quad 83$ Krawiec, supra note 81 , at 70-71, 78-84.

84 Wagner et al., supra note 49, at 124. $\quad 85$ Krawiec, supra note 81, at 79-80.

86 Wagner et al., supra note 49, at $125 . \quad{ }^{87}$ Id. at 125.

${ }^{88}$ Krawiec, supra note 81, at 82; Wagner et al., supra note 49, at 124-28.

89 Krawiec, supra note 81 , at $71-78$.

90 Id. at 71-78; Cynthia Farina, Mary Newhart \& Josiah Heidt, Rulemaking vs. Democracy: Judging and Nudging Public Participation that Counts, 2 Mich. J. Envtl. \& Admin. L. 123, 139-44 (2012). 
By contrast, the comments submitted by, or on behalf of, regulated firms are long, well-crafted, and rich in data and analysis. ${ }^{91}$ Regulated firms and their representatives submit the vast majority of the kinds of comments that have the potential to persuade decision-makers and to which courts require an adequate response in a statement of basis and purpose. They accounted for an average of 81 percent of all of the detailed comments submitted in the 90 rulemakings in which EPA issued air toxic emission standards. ${ }^{22}$ Parties who favored more strict air quality rules did not submit any comments in a majority of those rulemakings, and they accounted for an average of only 4 percent of all comments. ${ }^{93}$ Not surprisingly, 83 percent of changes that EPA made in response to comments weakened the proposed rule. 94 Once we have a clear picture of the nature and magnitude of the systemic bias in favor of regulated firms in the notice-and-comment rulemaking process it is relatively easy to identify the major sources of the bias. They include: collective action problems; judicial decisions that define an adequate notice and an adequate statement of basis and purpose; and judicial decisions that determine who has standing to obtain judicial review of rules.

\section{A Collective Action Problems}

Mancur Olson identified the most important source of bias in favor of regulated firms half a century ago. 95 When a public policy debate pits a large number of people, each with a small amount at stake, against a small number of people, each with a large amount at stake, the small number of people have a major advantage in the decision-making process. Consider, for instance, a decision whether to issue an air quality rule that would provide $\$ 3$ billion worth of benefits to a population of 300 million and that would impose costs of $\$ 1$ billion on ten regulated firms. Any economically rational decision-maker who has an accurate and complete understanding of the stakes would decide to issue the rule. The decision-maker is unlikely to obtain an accurate and complete understanding of the stakes, however, through the combination of meetings and comments that are the primary means through which agency decision-makers are educated in the rulemaking process.

Each of the 300 million potential beneficiaries of the rule has $\$ 10$ at stake. It would make no sense for any member of that group to spend more than \$10 to

91 Krawiec, supra note 81, at 74-78; Wagner et al., supra note 49, at 128-32.

92 Wagner et al., supra note 49, at 128-29. 93 Id. at 128-29. 94 Id. at 130-31.

95 Mancur Olson, The Logic of Collective Action: Public Goods and the Theory of Groups (1965). See also Wagner et al., supra note 49, at 128. 
learn about the issues in the debate and to attempt to influence the outcome of the debate. The issues in most such debates are complicated. Each of the 300 million beneficiaries is likely to remain rationally ignorant of the issues and impotent as a potential source of influence on decision-makers. Moreover, the transactions costs involved in any potential effort to form a group of potential individual beneficiaries that cooperate in an attempt to understand the issues and to influence the outcome of the debate are so high that beneficiary groups do not have sufficient resources to file effective comments in most major rulemakings.

Each of the ten firms that would bear the costs of the rule has $\$ 100$ million at stake. Each can rationally spend up to $\$ 100$ million to learn about the issues in the debate and to influence the outcome of the debate. An expenditure of even 10 percent of that amount is sufficient to hire the combination of talented lawyers and consultants required to participate effectively in meetings with decision-makers and to draft the kinds of detailed comments that are rich in data and analysis that are likely to be effective in persuading decision-makers not to issue the rule. Moreover, the benefits of engaging in a cooperative effort to persuade the agency not to issue the rule vastly exceed the transactions costs of organizing such an effort. Thus, each firm is likely to participate effectively in the decision-making process both individually and through a trade association.

\section{B Judicial Decisions Defining Notice and Statement of Basis and Purpose}

Courts have adopted two definitions of the "notice" an agency must issue as the first formal step in the rulemaking process. First, the notice must "adequately foreshadow" the final rule. ${ }^{6}$ Any significant difference between the rule proposed in the notice and the final rule increases the risk that a court will hold that the rule is invalid because the notice was inadequate. Second, the agency must identify in the notice any source of data or analysis that it will rely on in the statement of the basis and purpose the agency must incorporate in its final rule. 97

The first requirement gives agencies a powerful incentive to resolve all major issues in a rulemaking before it issues its notice, while the second provides a powerful incentive to minimize the time between the issuance of the notice

96 Wagner Electric Corp. v. Volpe, 466 F.2d 1013 (3d Cir. 1972). See generally Pierce, supra note 37 , at $\$ 7.3$.

97 Portland Cement Ass'n v. Ruckelshaus, 486 F.2d 375 (1973). See generally Pierce, supra note 37 , at $\$ 7.3$. 
and the issuance of the final rule. Taken together, they explain why the studies of the rulemaking process find that the pre-notice part of the process is twice as long as the post-notice part of the process and why, in the words of one of the researchers, the rule must be "essentially in final form at the proposed rule stage" in order to survive judicial review..$^{9}$ Of course, those findings are consistent with the finding that the pre-notice part of the decision-making process is more important than the post-notice part of the decision-making process and that the bias in favor of regulated firms is particularly powerful in the pre-notice part of the decision-making process.

Courts have held that the statement of basis and purpose that must be incorporated in a final rule must respond adequately to all well-supported comments that are critical of a proposed rule in order to avoid judicial rejection of the rule as arbitrary and capricious. 99 That requirement gives regulated firms and their representatives a powerful incentive to submit the kinds of detailed comments that are rich in data and analysis that they routinely submit. It provides a powerful incentive for agencies to make changes to proposed rules that are favored by regulated firms to avoid the risk of judicial rejection of the final rule based on a conclusion that the agency's response to the wellsupported comments was inadequate. It also provides a powerful incentive for agencies to avoid having to make such changes or to explain why they have not done so by proposing in the notice a rule that already incorporates the features that are favored by regulated firms. In short, these judicial decisions go a long distance in explaining both why the post-notice decision making process is biased in favor of regulated firms and why the pre-notice decision making process is biased in favor of regulated firms.

\section{Judicial Decisions on Standing}

A petitioner has standing to obtain judicial review of a rule if, but only if, it can establish that it has suffered a judicially cognizable injury that was caused by the agency action and that can be redressed by a court. ${ }^{100}$ Any regulated firm can establish easily that it has standing to obtain review of any rule that imposes costs on the firm, but courts often hold that an individual who is likely to benefit from issuance of a rule does not have standing to obtain review of a

$9^{8}$ Wagner et al., supra note 49, at 110 .

99 National Tire Dealers and Retreaders Ass'n v. Brinegar, 491 F2d. 31, 40-41 (D.C. Cir. 1974). See generally Pierce, supra note 37 , at $\$ 7.4$.

100 Ass'n of Data Processing Service Organizations v. Camp, 397 US 150, 152-5 (1970). The extremely complicated law that governs standing to obtain judicial review of an agency action is discussed in Pierce, supra note 37, at chapter 16. 
decision not to issue a rule that would have the potential to confer benefits on the individual. Thus, for instance, the D.C. Circuit issued an opinion in which it held that any regulated entity has standing to obtain review of any agency action $^{101}$ on the same day that it held that none of the six bases for standing claimed by beneficiaries of an agency was sufficient to support standing. ${ }^{102}$

The Supreme Court has refused to recognize injuries to potential beneficiaries of agency actions as sufficient to support standing because they are "shared with millions of others;" 103 they are not "imminent;"104 or, they are future injuries that are not "certainly impending." 105 It is also more difficult for potential beneficiaries to establish that the action they seek to have reviewed caused their injury ${ }^{106}$ or is redressable by a court. ${ }^{107}$ This asymmetric access to judicial review gives agencies an incentive to consider more seriously the views expressed by the firms who are regulated by a rule and who can take them to court than the views of the individuals who benefit from the issuance of a rule but who often lack the power to take the agency to court.

\section{THE EU USES NINETEENTH-CENTURY PROCEDURES SUCCESSFULLY}

\section{IN THE TWENTY-FIRST CENTURY}

The European Union (EU) has an executive branch, the European Commission, and a legislative branch, the European Parliament. The Commission uses a decision-making procedure roughly analogous to the US notice-andcomment process to create proposed legislation: "[A]ll proposals considered by the Council and the Parliament for actions that will have the force of law on Member States and all of their citizens... must originate with the Commission." 108

The Commission's procedure for creating a legislative proposal begins with publication of a "work plan" that is roughly analogous to a US agency's notice

101 National Ass'n of Home Builders v. EPA, 786 F.3d 34, 44 (D.C. Cir. 2015).

102 Turlock Irrigation District v. FERC, 786 F.3d 18, $23-25$ (D.C. Cir. 2015).

103 United States v. Richardson, 418 US 166, 176-77 (1974).

104 Summers v. Earth Island Institute, 555 US 488, 495-96 (2009).

105 Clapper v. Amnesty International, 133 S.Ct. 1138, 1147-48 (2013).

106 E.g., Allen v. Wright, 468 US 737, 756-57 (1984) (injury is not "fairly traceable" to the challenged government action because "the line of causation \& is attenuated" and is dependent on the action of some third party.").

107 Steel Co. v. Citizens for a Better Environment, 523 US 83, 106-07 (1998) (civil penalties cannot redress an injury to individuals).

108 Comparative Law and Regulation: Understanding the Global Regulatory ProCESs (Francesca Bignami \& David Zaring eds., 2016); Peter Strauss, Rulemaking in the Ages of Globalization and Information: What America Can Learn from Europe and Vice Versa, 12 Colum. J. Eur. L. 645, 651 (2006). 
of proposed rulemaking. ${ }^{109}$ The Commission then engages in "consultation." Consultation is roughly analogous to solicitation of comments in the U.S. ${ }^{110}$ It differs, however, in both its rigor and its results: "[C]ommission consultations tend to be quite structured in character, requiring responses to a series of questions about identity and interest and then asking particular questions about the matter under study." ${ }^{111}$

The comments elicited through this highly structured process differ from those received by a US agency in a major rulemaking. Professor Strauss's description of the results of one Commission consultation with respect to a major legislative proposal illustrates the differences. There were:

968 participants in an Interactive Policymaking tool that was, in part, a structured questionnaire, and a total of 6400 comments of varying length and detail... in contradistinction to the American rulemaking processes of equivalent controversiality, virtually all of these comments appear to have spoken to the proposals in knowledgeable detail. ${ }^{112}$

As Professor Strauss noted, the contrast with the US notice-and-comment process is stark. The vast majority of the comments filed in a typical major US rulemaking are worthless to decision-makers because they consist of brief assertions with no supporting data or analysis. ${ }^{113}$

The process of creating a legislative proposal in the EU also includes an assessment of the expected impact of the proposal. This step is roughly equivalent to the cost-benefit analysis (cba) that the Office of Information and Regulatory Affairs (OIRA) implements with respect to major rules proposed by US agencies, though it differs in some important respects from its US analogue. Thus, for instance, it is broader in scope than a cba; it includes assessment of the likely environmental impact of the proposal. It is also accomplished through use of a far more publicly visible procedure than the largely opaque OIRA review process. ${ }^{114}$

The biggest differences between the US and EU decision-making procedures are apparent in the explanations of the rules that emerge from the process. The typical explanation of an EU rule is about eight pages long, compared with the 200- to 2000-page statement of basis and purpose that usually accompanies a major rule issued by a US agency. ${ }^{115}$ That difference undoubtedly is attributable to the differing roles that the judiciary play in the US and the EU. US courts invariably review all major rules through use of an approach

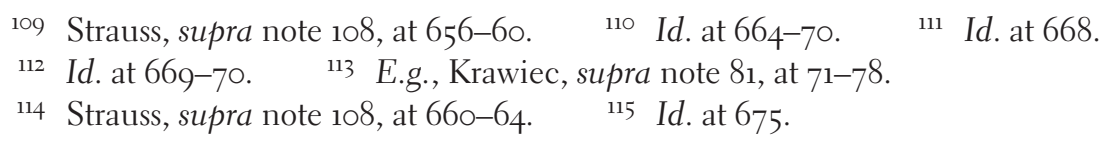


that requires an agency to write an extremely lengthy and detailed statement of the basis and purpose of the rule to have any chance of persuading a US court to uphold a major rule. Courts play no role in the decision-making process in the EU. The architects of the EU decision-making process acted on the belief that "[s]uch an over-legalistic approach would be incompatible with the need for timely delivery of policy, and with the expectations of the citizens that the European Institutions should deliver on substance rather than concentrating on procedures." $" 16$

\section{HOW CAN WE MOVE BACK TO THE FUTURE?}

In theory, Congress can move us back to a time in which agencies could function efficiently and effectively without an army of lawyers. Congress could amend the APA in ways that reduce significantly the role of courts. There are two problems with this potential solution, however. First, it is unlikely to happen. It has always been difficult to get the House, the Senate, and the President to agree on an amendment to the APA, and that difficulty has increased significantly in recent years as a result of increased political polarity. ${ }^{117}$ Second, changes in the language of the APA might not be effective in any event, given the potential for the courts to distort the APA to suit their preferences, as illustrated by the judicial interpretations of "notice" and "concise general statement of basis and purpose."118

Since the excessive proceduralization of the rulemaking process was caused primarily by judicial decisions that adopted interpretations of the APA that bear no relationship to the language of the statute, courts can, and should, eliminate the problems they have created by adopting interpretations of the APA that are based on the language of the APA. Thus, for instance, the "concise general statement of basis and purpose" required by APA section 553 cannot possibly refer to a judicially required statement that must be hundreds or thousands of pages long and that still has a 30 percent probability of being determined to be inadequate by a court. ${ }^{119}$

116 Id. at 665 .

117 Thomas Mann \& Norman Ornstein, It's Even Worse Than It Looks: How the American Constitutional System Collided With the New Politics of Extremism (2013).

118 See supra text accompanying notes 21-55.

119 See supra text accompanying notes 15-17. Jacob Gersen and Adrian Vermeule have made a strong case for a significant reduction in the intensity with which courts apply the arbitrary and capricious test to rulemakings in Thin Rationality Review, 114 Mich. L. Rev. 1355 (2016). 
The courts could go farther by eliminating the dubious presumption of reviewability of agency action, ${ }^{120}$ or at least the unsupportable presumption of pre-enforcement review, as a majority of Justices once suggested. ${ }^{121}$ The courts could expand the scope of APA section 701(a)(2) - the exemption from judicial review applicable to "agency action that is committed to agency discretion by law"122 - by adopting an interpretation that is consistent with the famous dictum in Marbury v. Madison: "The province of the courts is solely to decide on the right of individuals, not to enquire how the executive or executive officers, perform duties in which they have a discretion." 123

Consistent with that famous precedent and many others, the courts could interpret the Case or Controversy requirement of Article III to prohibit courts from engaging in pre-enforcement review of agency rules. ${ }^{124}$

\section{CONCLUSION}

There are two primary differences between nineteenth-century agencies and modern agencies. First, nineteenth-century agencies were more efficient and effective than modern agencies as measured by the number of rules issued and the effects of the rules issued. Second, while actions taken by modern agencies are subject to judicial review, actions taken by nineteenth-century agencies were not. The two differences are closely linked. During the period 1967 to 1974 , courts issued decisions that require agencies to use inefficient procedures that consume enormous quantities of agency resources and create years of delay in the process of issuing, amending, or rescinding a major rule.

The high cost of those judicially mandated procedures might be acceptable if they improved significantly the results of the rulemaking process and if we could afford to continue to absorb those costs. Neither of those conditions exist.

There is no evidence that the judicially mandated procedures improve the quality of the resulting rules. To the contrary, there is considerable evidence that they introduce powerful systemic bias in the rulemaking process. We also cannot continue to absorb the high costs of the judicially mandated procedures. They are already creating intolerable delay in the agency decisionmaking process, and the significant reductions in the resources available to agencies that are inevitably consistent with fiscal policy constraints will render them far less affordable in the future.

\footnotetext{
120 Bagley, supra note $18 . \quad{ }^{121}$ Shalala v. Illinois Council on Long-Term Care, 529 US 1 (2000). 1225 USC $\int 701(\mathrm{a})(2) . \quad 1235$ US 137, $170(1803)$.

124 Mashaw \& Harfst, Auto Safety, supra note 2, at 157.
} 
The courts can solve this problem by overruling their decisions of the late 1960s and early 1970s that adopted interpretations of the APA and the Constitution that conferred on courts far more power over agency decisionmaking than the language of either document can support. By correcting their prior errors, the courts can restore the traditional legal regime in which agencies could perform their functions efficiently and effectively. 